\title{
Domestic violence: possibilities and limitations in coping ${ }^{1}$
}

\author{
Angelina Lettiere ${ }^{2}$ \\ Ana Márcia Spanó Nakano ${ }^{3}$
}

\begin{abstract}
This qualitative study assesses how women, in situations of domestic violence and examined at the Institute of Forensic Medicine, deal with this adversity and identifies protection strategies to cope with it, considering the support required and obtained from their relational and institutional environments. Ten women were interviewed and the data were analyzed using thematic content analysis. Search for help primarily occurs in the women's social milieu, with family and friends and health and legal services being sought. In such a quest, established bonds may either become an obstacle to coping and make these women vulnerable to violence or protect and strengthen them during coping. In the identification of these women's social and health needs, the aggravating circumstances of violence are only superficially addressed by professionals. New strategies to implement professional actions should be devised in order to provide integral and humanized care.
\end{abstract}

Descriptors: Domestic Violence; Women's Health; Social Support.

\footnotetext{
${ }_{1}$ Paper extracted from Master's Thesis "Violência doméstica sob o olhar das mulheres atendidas em um Instituto Médico Legal: as possibilidades e os limites de enfrentamento da violência vivenciada", presented to Escola de Enfermagem de Ribeirão Preto, Universidade de São Paulo, WHO Collaborating Centre for Nursing Research Development, SP, Brazil. Supported by Conselho Nacional de Desenvolvimento Científico e Tecnológico (CNPq), process \# 130218/2009-0.

${ }^{2}$ RN, Master's student in Nursing, Escola de Enfermagem de Ribeirão Preto, Universidade de São Paulo, WHO Collaborating Centre for Nursing Research Development, SP, Brazil. E-mail: angelinalettiere@yahoo.com.br.

${ }^{3}$ RN, Ph.D. in Nursing, Full Professor, Escola de Enfermagem de Ribeirão Preto, Universidade de São Paulo, WHO Collaborating Centre for Nursing Research Development, SP, Brazil. E-mail: nakano@eerp.usp.br.
}

Corresponding Author: Ana Márcia Spanó Nakano Universidade de São Paulo. Escola de Enfermagem de Ribeirão Preto Departamento Materno-Infantil e Saúde Pública

Av. dos Bandeirantes, 3900

Bairro: Monte Alegre

CEP: 14040-902, Ribeirão Preto, SP, Brasil

E-mail: nakano@eerp.usp.br 


\section{Violência doméstica: as possibilidades e os limites de enfrentamento}

O objetivo do presente estudo foi compreender como as mulheres em situação de violência doméstica, atendidas no instituto médico legal, convivem com essa adversidade e identificar as estratégias de proteção no enfrentamento, considerando o apoio/ suporte requerido e o obtido no meio relacional e institucional. Trata-se de estudo com abordagem qualitativa. Foram entrevistadas dez mulheres e os dados analisados pela técnica de análise de conteúdo, modalidade temática. A busca por ajuda ocorre no próprio meio social, junto à família e amigos. Posteriormente, recorre-se aos serviços de saúde e judicial. Nessa busca, os vínculos estabelecidos podem se tornar obstáculo ao enfrentamento e, portanto, vulneráveis à violência, ou podem proteger as mulheres e fortalecê-las no enfrentamento. No reconhecimento de suas necessidades sociais e de saúde, os agravantes da violência são apenas tangenciados pelos profissionais, na apreensão das necessidades dessas mulheres. Para o atendimento integral e humanizado devem ser pensadas novas estratégias de ações profissionais.

Descritores: Violência Doméstica; Saúde da Mulher; Apoio Social.

\section{Violencia doméstica: las posibilidades y los límites de enfrentamiento}

El objetivo del presente estudio fue comprender como las mujeres en situación de violencia doméstica, atendidas en el Instituto Médico Legal, conviven con esta adversidad e identificar las estrategias de protección en el enfrentamiento, considerando el apoyo/ soporte requerido y el obtenido en el medio relacional e institucional. Es un estudio de abordaje cualitativo. Se entrevistaron diez mujeres y los datos fueron analizados por la técnica de análisis de contenido, en la modalidad temática. La búsqueda por ayuda ocurre en el propio medio social, junto a la familia y amigos. Posteriormente, se recurre a los servicios de salud y judicial. En esa búsqueda los vínculos establecidos se pueden tornar un obstáculo al enfrentamiento y, por lo tanto, vulnerables a la violencia, o pueden proteger a las mujeres y fortalecerlas en el enfrentamiento. En el reconocimiento de sus necesidades sociales y de salud, los agravantes de la violencia son tocados apenas tangencialmente por los profesionales en la aprehensión de las necesidades de estas mujeres. Para la atención integral y humanizada deben ser elaboradas nuevas estrategias de acciones profesionales.

Descriptores: Violencia Doméstica; Salud de la Mujer; Apoyo Social.

\section{Introduction}

The impact of violence is evident in the world, since more than a million people lose their lives and many others suffer non-fatal injuries every year as a result of self-inflicted, interpersonal or collective violence(1). According to the Pan-American Health Organization, the interface between violent acts and health occurs because the health sector is a point where all cases that result from such acts converge, as well as due to the pressure victims of violence exert on urgent care services, specialized services and those of physical and psychological rehabilitation and social work(2).

Violence, as a complex phenomenon, can be seen in its distinct forms, particularly in the context of aggressive acts against women, and the object of this study. In relation to this fact, the UN General Assembly approved the declaration on the elimination of violent 
acts against women in 1993 and defined the targeted acts as: "any act of gender-based violence that results in, or is likely to result in physical, sexual or mental harm or suffering to women, including the threat of such acts, coercion or arbitrary deprivation of liberty, whether in public or private life"(3).

Women are at a greater risk of being abused in relationships with family members or people close to them than they are of being abused by strangers. Most of time, the aggressor is the partner or spouse themselves ${ }^{(4)}$; the cause and consequence of such aggression is unequal power in gender relations ${ }^{(5)}$.

Domestic or gender-based violence affects the victim's biopsychosocial integrity. The symptoms and developmental disorders that may manifest as a consequence of violence are diverse, such as: diseases of the digestive and circulatory systems, muscle pain and tension, menstrual disorders, depression, anxiety, suicide, drug use, posttraumatic stress disorder, in addition to physical injuries, deprivation, and murder of the victim(6-7).

The reception of women in situations of domestic violence in health services occurs in a fragmented way and is usually a one-time action because professionals are not prepared to meet this demand in an integral manner. In clinical practice in which such actions tend to remain invisible, the conduct of health professionals is not to welcome the needs of these women; rather, health professionals restrict their actions to referrals, which do not always result in appropriate responses to the women's demands( ${ }^{(8)}$. In this context, we sought to understand how women who were in situations of domestic violence and examined at the Institute of Forensic Medicine in the interior of São Paulo, Brazil deal with situations such as adversity. The study identifies protection strategies against violence, considering the support required and obtained through relational and institutional means, in terms of recognizing and meeting the women's needs.

This study is justified by the fact that responses in the specialized literature are insufficient given the facts that may protect women from the cycle of violence. This study is an important contribution to the health field, especially in the nursing field, because we believe that the understanding of this issue allows one to provide more effective care to women and devise strategies that include multidisciplinary care and cooperation among sectors of society to provide integral and humanized care, in addition to promoting prevention strategies and reducing the occurrence of aggression episodes.

\section{Method}

This descriptive study with a qualitative approach was carried out in a city in the interior of São Paulo, Brazil. It focused on the health services, and also on the social devices and public security that compose the institutionalized network that provides support to abused women. The study's setting was the Center for Medical-Legal Forensics, specifically the Institute of Forensic Medicine.

Women who report domestic violence to Women's Police Stations are referred to the Institute of Forensic Medicine, especially in the case of bodily injuries, to receive a forensic examination. Hence, the choice of this institution to collect data is justified because this is where women with a pro-active profile are found, which may reveal one's response to problems and also reveal prior passive behaviors.

The empirical outline of this study was determined by data saturation criteria, that is, when information starts to become recurrent. A total of ten women older than 18 years old who suffered domestic violence and were assisted in the studied institution participated in this study.

Because this study involved human subjects, it complied with the requirements established by resolution $196 / 96$ of the National Council of Health ${ }^{(9)}$. Data collection was initiated only after the Ethics Research Committee at the University of São Paulo, College of Nursing approved the project (Protocol no 1029/2009).

Data collection was conducted in the institute's facilities between December 2009 and August 2010. The women were invited to participate in the study while in the waiting room and by the order they arrived at the service. Data collection occurred in a private room to avoid hindering the service flow and only after the forensic exam was performed.

The women were informed of the study's objectives through a free and informed consent form read by the researcher. Those who consented to participate in the study signed the form and then the interview was initiated. The participants received a copy of the consent form signed by both the researcher and themselves. To ensure confidentiality of information and the names of the interviewees, the testimonies are identified by the letter " $E$ " followed by a number from one to ten according to the order of the interviews.

Data were collected through a semi-structured interview in which the participants had a chance to talk about the subject without being necessarily tied to a 
specific question $^{(10)}$. Aiming to produce empirical material, we developed an interview script with open questions addressing basic information such as: identification of the participants, issues related to coping actions and the repercussions of violence in their lives and on their health, keeping the guiding question in mind, that is, what factors can protect these women from the cycle of violence. After the end of the interview, each participant received a list of the health services that support women in this situation.

The testimonies were recorded and transcribed verbatim. Data were analyzed through thematic content analysis(11). The thematic analysis followed the steps of comprehensive reading, exploration of the material and interpretative synthesis(12). The following concepts were incorporated in the analysis of results: protection factor and integrality in the context of the social network to cope with violence against women.

\section{Results}

As previously mentioned, the studied group was composed of ten women in situations of domestic violence. In $90 \%$ of the cases, the aggressions were perpetrated by the study member's current partner, and in $10 \%$ of the cases by a former partner; $50 \%$ were single and lived with the partner at the time of the interview, $20 \%$ were married and $30 \%$ were separated.

All the studied women suffered physical violence, though in some cases it was associated with other types of violence. A total of $20 \%$ of the interviewees reported only physical violence. In addition to this type of aggression, $50 \%$ also reported psychological violence, $20 \%$ sexual violence and $10 \%$ false imprisonment.

The average age of the interviewees was 38 years old, and the ages ranged from 24 to 62 years old. In relation to their occupation, $60 \%$ of them had a paid job, $30 \%$ were homemakers and $10 \%$ were unemployed. In relation to schooling, $50 \%$ had incomplete primary school, $10 \%$ had completed primary school, 30\% had completed secondary school and $10 \%$ had a bachelor's degree. The average number of children per women was two, with a range from one to four children. When they were asked about their race, 50\% reported being of mixed race, $40 \%$ Caucasian, and $10 \%$ reported to be Afro-Brazilians. In relation to their religion, 30\% reported to be Evangelical, 40\% Catholic, and 30\% reported no religion.

The following main category emerged from the analysis of the interviews: Recognizing the social support network one has available and the expectations of needs. In this category we identify the following core meanings: a) 'Search for help: from silence to a cry of help'; b) 'Social support network: protection and vulnerability'; and c) 'Recognizing one's social and health needs'.

In the first core meaning, 'search for help: from silence to a cry of help', we verify that violence is silenced until some measure is taken, as shown in the following excerpt: I had to hide it from my father, my mother, my brothers and sisters, from family. I had to hide everything. I had to face it all by myself. It was really hard, very hard! (E10).

When the studied women took the initiative to seek help, when they broke silence, it primarily occurred in their own closest social milieu, such as with the family and friends: So, my family is currently helping me (E6). Look, I asked for help, for someone to come and get me... Then some friend would show up and get me... You know? So, everybody has always helped me (E3).

Given the limitations of the family to help solve the problem, these women seek help in other places such as religious institutions. Even when the institution is not present, spirituality helps them in some way to bear or cope with the problem, as the following excerpt reveals: I believe in God, I believe in divine justice that is coming, you know. Because I've become disappointed by men in leadership, you know. So, if it weren't for my faith that everything would be okay, that everything ends well...(E6).

Depending on the consequence of violence on the victim's health and how they perceive the severity of the situation, seeking out a health service is not only a resource to solve physical injuries but mainly to help them deal with psychological harm as the following excerpts exemplify: No, first I went to get stitches (emergency department) and then I went to fill in a police report (E7). I started going for psychological treatment... With a psychiatrist and a shrink (E3).

The victims seek other instances in the network such as the safety sector, e.g., the women's police station, as shown in the following reports: I wanted justice. At the time I wanted justice. At the time I dialed the emergency number (E6). I went to the women's police station (E4).

In the second core meaning, 'social support network: protection and vulnerability', they broke their silence and sought help, which initially occurs within the family and with friends, as already mentioned. These can protect them from violence, when care is focused on the women, and also provide financial help as the reports reveal: It is hard to cope. But, at the same time, it is not so hard because you have care and affection (from the family). If had done this the first time, there would not be a 
second time (E2). Everybody supports you. You see. So, I have lots of friends. We are not alone in this world, no. So, why will I be beaten up? One friend told me I'll not go hungry, she said she'd give me a basket of food in the meantime. Another one says that too. You see (E7).

If, however, there is no family cohesion or ties; the impact is vulnerability in the face of violence. The women become isolated and have no effective support as indicated in the reports: My mom has not called me so far to say 'let's talk' (E8). Ah, my family went only once. I called my aunt. My aunt lives in Leme (a town in the interior of São Paulo) and I said: "Oh I, I'll go somewhere far away, I'll disappear with my son and I need you to stay with my mom. Because my mom depends on me. I'd rather she stay with her sister so I can solve my problems. So she said: "This is your problem! You have to stay with your mom. Take care of it yourself" (E1).

In relation to the church institution, it is possible to notice that it offers support, especially emotional support, as observed in the reports: It helped me get rid of hurt feelings, that sadness in my heart and it gives me strength to go on. Because the church helps me a lot, down there, inside. Because on the outside, there has to be something stronger to deal with him, so people can see we're not abandoned to our very fate (E8).

In relation to the health services, we see these care for what is apparent: I went to the hospital and I thought they had filled in a police report (E2). I was cared for right away because I was bleeding, you know. The knife was still hanging because I could not take the knife out of my back (E7).

In relation to the intervention of the police, the women use this resource because of the chance to have protection: I hope the judge issues a restraining order against him and I can keep the house because I have my daughters to raise (E5). I've sought help because I can't take it anymore and if something happens to me I want people to know. You see... that he's involved. I don't think anything will happen, but if it happens there's already a clue (E4).

However, there are times, as opposed to what they might expect, that the search for their rights would be a mark of rupture with their condition of victims; they see themselves dealing with a reality of helplessness and disbelief in justice. It is a slow process. It's bureaucratic, now we have to go to many agencies. Every time I need I'll have to come here. So, the conclusion of the facts is very complicated, but like today I feel I'm not in danger anymore in relation to him, not me or G (E6). But it is too slow for the Penha Law* to get into effect. To take him out of the house. It took seven months for them to contact me. I'd only like the law to be faster. Maria da
Penha law. Faster! (E7).

In the last core meaning, 'recognizing their social and health needs among the consequences of violence', the most evident needs in these women's testimonies are those of a psychological nature. In emotional terms, the person's self-esteem, because we think it's nothing (E8). So, it messed with my emotions a lot, with my psychosomatic issues. So, he made me extremely distressed. He literally made me crazy (E6). If affected me yes. Affected me because I have nervous gastritis and he beat me up too much. I don't like to...I don't like to remember the way he took my head and hit it on the ground (E4).

This reality can be seen because psychological disorders are not addressed by the professionals as the women expected, which is shown in their testimonies: Because there are doctors who like... Who do what they have to do. They don't think about the person's psychological dimension (E3). I've been going to this psychiatrist for 15 years. Because what I say enters here (ear) and goes out here (other ear) (E10).

Violence can harm health but it also affects interpersonal relationships, social institutions and society as a whole as changes are perceived in social relationships, especially in relation to friends and neighbors: I've distanced myself from everybody. I've distanced myself because I thought that if I had a friend, she would find out and would tell and another person would know, and another, the daughters-in-law would know (E10). Now people become more cautious in getting close to you, talk to you, because you've distanced yourself from people for so long, people get like... so... what is happening... then people kind of distance themselves from you also (E3).

\section{Discussion}

This study allowed us to get closer to the experiences of these women in situations of violence, the strategies they adopted and decisions they made, what revealed to them the face of possibilities and limitations to cope with such an adversity.

In the paths they chose to seek help, they go from silence to a cry for help. Even though the interviewees reported these choices, this trajectory requires careful analysis, since in qualitative terms, it shows differences in the processes of personal transformation and social conditions of each of these women. Power between genders permeates the situation of all of them but it is not the only hierarchical factor in the context of social relationships, which may explain differences in the

*Law 11.340/06 known as Law Maria da Penha in honor to Maria da Penha Maia Fernandes who struggled for 20 years to have her aggressor, who tried to kill her twice and left her paraplegic, in jail. 
coping process. Violence against women is trivialized, minimized, denied by a sexist and chauvinistic culture, perceived by society as something that could not be avoided $^{(13)}$.

Therefore, the strategies these women use to offer resistance and which are constructed in their daily routine are in reality empowerment strategies, that is, they contribute, in the feminist conception, to relationships between men and women being accompanied by a transformation in language, reflecting new constructions of social imaginary ${ }^{(14)}$.

In coping with this problem, women take paths that involve the interaction of intra-psychological and social processes such as family and institutional relationships, which may be either relationships of risk of or protection against violence. We understand that the family context is a factor that can protect since the family interacts with external factors and leads to reconstruction in the face of suffering and is an influence that can modify, improve or entirely change the response of a person if the face of hardship, that is, in the face of a violent act(15).

However, some women are isolated from their family and social network, which may facilitate the aggressor's control over the victim and perpetuate the cycle of violence. For this cycle to be broken, a network connected to services that support women in this situation is required(16).

The family and safety and health institutions are included among the social resources used, constituting their support social network. There are diverse entryways into this route, that is, different services that should cooperate with each other to provide qualified care to women ${ }^{(17)}$. Also important is that such care is continued, aspects that are identified in the testimonies of the studied interviewees.

The World Health Organization recommends the qualification of health professionals in this context to recognize and address violence through welcoming and acknowledging the wholeness of women as individuals with human rights, informing them of the resources available in society such as the women's police station and shelters, in addition to recognizing situations that pose a risk to their lives, working in cooperation with other sectors in society to protect them ${ }^{(5)}$. However, the reception of these women occurs in a fragmented way and without a commitment to continued care, both in terms of physical and emotional rehabilitation and social and legal rehabilitation ${ }^{(18)}$.

The bonds established with the network are, in this group, reduced to health services (the emergency department), showing greater evidence of psychotherapy, caring for what is more visible and evident, with palliative and limited solutions to meet the women's needs, which makes the network a fragile and unstructured support.

In relation to the health professionals, knowledge concerning care provided to women was addressed by a study published in this periodical. The study addresses the meaning of the experience of health professionals in caring for victims of sexual violence. The main theme emerging from this study was the feeling of powerlessness to solve the situation of violence, problems that emerge from the individual's subjectivity, as well as social issues and also in not recognizing the resources and possibilities available to cope with the problem ${ }^{(19)}$.

A remarkable fact is the psychologization of the violence issue, which is a way of the health services to avoid facing the problem. When one medicalizes the body of an abused woman, one reaffirms the medical ideology of defining the reality presented, that what is apparent, obscuring the problem's social, political, and cultural roots $^{(20)}$. Hence, the knowledge of another's subjectivity and biopsychosocial issues are not addressed in the biomedical model that values practical and short-term results ${ }^{(19)}$.

In addition to health services, women also seek public safety services, especially women's police stations. For them, these services represent a mark of rupture with their condition as victims, based on the Maria da Penha law that will protect them from the aggressor and enact justice. The Maria da Penha law amends the Criminal Code, allowing aggressors to be caught redhanded or have their custody enacted. It also stipulates the creation of a special court for domestic and family violence against women, aiming to speed up processes and protective measures, among them, forcing the aggressor to leave home, protecting children and the women's rights to reclaim their property ${ }^{(21)}$. However, the studied women complain of the lengthy processes, which leave them insecure in the face of what they are exposed to.

The way women addressed in these studies perceive their needs may change depending on their historical and social background and the context of social support they receive. During the coping process, the women guide themselves based on the needs that can be addressed by social institutions (health and safety), that is, those of a normative nature, which have limited access to aspects of their integrity. The aggravating factors of violence for these women's health and their life conditions are only slightly addressed by the professionals while meeting 
their needs.

Over the course of the studied group's reports, we perceived that the social network set up and used by them provides both greater and lesser bonds. This indicates that the network still presents very fragile bonds and relationships and that the integration among all services and sectors, which would effectively form a protection network, despite advancement in the field, still fall short of the reality experienced by the study's subjects.

We believe there is a dichotomy between what is recommended and what is experienced in the routine of these women in relation to the development and work of the network in coping with violence; such institutions do not effectively play their role protecting these individuals. Hence, to truly fulfill their protection role, social support networks should work toward producing flexible ecological systems ${ }^{(22-23)}$

A study conducted by the Special Secretary of Women's Public Policies revealed that the violent act is often cyclical because women experience many obstacles and lack effective measures while seeking protection, which results in emotional weariness and a return to the situation of violence ${ }^{(24)}$.

\section{Conclusion}

This study's results show that despite the advancements obtained in recent years in the field, "critical knots" still persist in these women's coping trajectories to break their silence, denounce and overcome the violence suffered. This study is expected to support the creation of helping strategies and make them more effective in order to strengthen the support network focused on violence against women.

Aiming to encourage professionals to rethink the way care is provided to women in this situation, especially in relation to nursing care, it is important that professionals who deal with these women appropriate new knowledge, including diverse fields of knowledge, partake in inter-disciplinary and intersector discussions to support and improve practices so that the principle of integrality in care delivery is a product of our practices in health. It means to think of health care not only as an instrumental or technical knowledge, but also as knowledge that permits one to understand the phenomenon as a dynamic process, related to the different universes of signification and re-signification.

In this context, it is essential to incorporate the topic of violence into the discipline of women's health from the perspective of gender, as well as interdisciplinary perspectives from the fields of public and collective health. Therefore, a broader knowledge of the phenomenon promotes a more critical reflection concerning women's health and life conditions, contributing to planning nursing care, including prevention, care delivery, rehabilitation up to the re-inclusion of these women within society.

A connected work that includes health sectors, safety, education, social wellbeing and the legal sector is essential in inter-sectorial action in order to work in a responsible and cooperative way to broaden the possibilities of constructing strategies to respond in an integral manner to these women's needs and help them to overcome harm and other consequences of such violence on their health and their living conditions and that of their families'.

\section{References}

1. Krug EG, Dalhberg LL, Mercy JÁ, Zwi AB, Lozano R, editors. World report on violence and health. Geneva (CH): World Health Organization; 2002.

2. Organização Pan-americana da Saúde. Violência y salud. Washington (US): OPAS: 1994.

3. United Nations. Declaration on the Elimination of Violence against Women. General Assembly resolution no. A/48/104 of 20 Dec 1993. Geneva; 1993. Disponivel em: http://www.un.org/esa/gopher-data/esc/cn6/198693/e1993-27.en/

4. Kronbauer JFD, Meneghel SN. Perfil da violência de gênero perpetrada por companheiro. Rev Saúde Pública. 2005;39(5):695-701

5. World Health Organization. Multi-country study on women's health and domestic violence against women. Geneva (CH): World Health Organization; 2005.

6. Carlson BE, Mcnutt LA, Choi D, Rose IM. Intimate partner abuse and mental health: the role of social support and others protective factors. Violence Against Women. 2002;8(6):720-45.

7. Loxton D, Schofield M, Hussain R, Mishra G. History of domestic violence and physical health in midlife. Violence Against Women. 2006;12(8):715-31.

8. Lettiere A, Nakano AMS, Rodrigues DT. Violência contra a mulher: a visibilidade do problema para um grupo de profissionais de saúde. Rev Esc Enferm USP. 2008;42(3):467-73.

9. Ministério da Saúde (BR). Resolução no. 196/96 Diretrizes e Normas Regulamentadoras de Pesquisa 
Envolvendo Seres Humanos. Brasília: Conselho Nacional de Saúde; 1996.

10. Minayo MCS. O desafio do conhecimento: pesquisa qualitativa em saúde. São Paulo: HUCITEC; 2008. 406 p.

11. Bardin L. Análise de conteúdo. 5 ed. Lisboa: Edições 70; 2009. $281 \mathrm{p}$.

12. Gomes R. Análise e interpretação de dados de pesquisa qualitativa. In: Minayo MCS, Deslandes SF, Gomes R. Pesquisa social: teoria, método e criatividade. Rio de Janeiro (RJ): Vozes; 2008. p. 79-108.

13. Strey MN. Será o século XXI o século das mulheres? In: Strey MN, Mattos F, Fensterseifer G, Werba GC. Construções e perspectivas em gênero. Leopoldo: Unisinos; 2000. p. 9-18.

14. León M. Empoderamiento: relaciones de las mujeres com el poder. Estud Feministas. 2000;8(2):191-205.

15. Assis GG, Pesce RP, Avancini JQ. Resiliência: enfatizando a proteção dos adolescentes. Porto Alegre: Artmed, 2006. 144 p.

16. Hirigoyen MF. El acosso moral: el maltrato psicológico en la vida cotidiana. Buenos Aires: Paidós; 2000.

17. Presidência da República (BR). Secretaria Especial de Políticas Públicas para as Mulheres. Informativo: Política Nacional de Enfrentamento à Violência contra as Mulheres. Brasília (DF); 2008.

18. Santi LN, Nakano, AMS, Lettiere A. Percepção de mulheres em situação de violência sobre o suporte e apoio recebido em seu contexto social. Texto Contexto Enferm. 2010;9(3):417-24.

19. Correa MEC, Labronici LM, Trigueiro TH. Sentir-se impotente: um sentimento expresso por cuidadores de vítimas de violência sexual. Rev. Latino-Am. Enfermagem. [periódico na Internet]. maio-jun 2009 [acesso 05 jun 2011]; 17(3):[06 telas]. Disponível em: http://www. scielo.br/scielo.php?script =sci_arttext\&pid=S0104$11692009000300002 \&$ Ing $=$ pt.

20. Grossi PK. Violência contra a mulher: implicações para os profissionais. In: Lopes MJM, Meyer DE, Waldow VR. Gênero \& saúde. Porto Alegre: Artes Médicas; 1996. p. 133-49.

21. Jon LC, Sadala MLA, Tanaka ACD. Desistindo da denúncia ao agressor: relato de mulheres vítimas de violência doméstica. Rev Esc Enferm USP. 2008;42(4):744-51.

22. Poletto RC, Koller SH. Rede de apoio social e afetivo de crianças em situação de pobreza. Psico-PUCRS. 2002;33:151-76.

23. De Atoni C, Koller SH. O psicólogo ecológico no contexto institucional: uma experiência com meninas vítimas de violência. Psicol Ciênc Profissão. 2001;21(1):14-29.
24. Secretaria Especial de Políticas Públicas (BR). Programa de Prevenção, Assistência, e Combate à Violência Contra a Mulher - Plano Nacional. Brasília (DF); 2003.
Received: Dec. $3^{\text {rd }} 2010$ Accepted: Ago. 10 2011 